\title{
The corollary effect of heavy metal accumulation in freshwater ponds on the hematological profile of Nile Tilapia (Oreochromis niloticus)
}

\author{
Gemerlyn G. Garcia' ${ }^{1}$, Elaine Jean L. Miguel ${ }^{1}$, Mark Anthony L. Gabriel ${ }^{1}$, Claro N. Mingala ${ }^{2,3 *}$ \\ ${ }^{1}$ College of Veterinary Science and Medicine, Central Luzon State University, Science City of Muñoz 3120, Nueva Ecija, Philippines \\ ${ }^{2}$ Philippine Carabao Center National Headquarters and Gene Pool, Science City of Muñoz 3120, Nueva Ecija, Philippines \\ ${ }^{3}$ Department of Animal Science, College of Agriculture, Central Luzon State University, Science City of Muñoz 3120, Nueva Ecija, \\ Philippines
}

${ }^{*}$ Corresponding author, E-mail: cnmingala@hotmail.com

\begin{abstract}
The status of heavy metal buildup in commercial and non-commercial ponds of Nile tilapia (Oreochromis niloticus) and its effect on fish health was evaluated. Pond water and tilapia meat were examined for $\mathrm{Pb}$, As, cadmium $\mathrm{Cd}$ and $\mathrm{Cu}$ using flame atomic absorption spectrometry; and $\mathrm{Hg}$ through manual cold-vapor atomic absorption spectrometry. Standard methods in hematology were applied to estimate red and white blood cell function of fish in relation to heavy metal accumulation. The results revealed significantly higher $\mathrm{Cu}$ content in pond water of a commercial farm compared to the $\mathrm{Cu}$ content of water from a non-commercial farm, while similar levels of $\mathrm{Hg}$ and $\mathrm{Pb}$ were recorded. Tilapia meat from commercial ponds had significantly higher $\mathrm{Pb}$ and lower levels of $\mathrm{Cu}$ compared to meat from a non-commercial farm. Similar levels of $\mathrm{Hg}$ were observed in tilapia meat obtained from farms while tilapia meat from non-commercial ponds had significantly higher $\mathrm{Cu}$. Neither As nor Cd were detected in the farms. Hematological evaluation revealed comparable counts of total red blood cell. Red blood cell indices such as hematocrit and mean corpuscular volume were significantly higher in tilapia from the commercial ponds. The amount of hemoglobin per red blood cell was smilar in tilapia from the farms while mean corpuscular hemoglobin concentration was significantly higher in tilapia from the non-commercial farm. Total white blood cell and eosinophil counts of tilapia were similar in the farms. Tilapia from the commercial ponds had significantly high neutrophil and monocyte counts while tilapia from the non-commercial ponds had significantly high lymphocyte counts. The hematological evaluation indicate relationship of cellular components of fish blood and heavy metal accretion from the aquatic environment by Nile tilapia.
\end{abstract}

Key words: eosinophils, fish flesh, heavy metals, hematological parameters, Nile tilapia (Oreochromis niloticus), pond water.

Abbreviations: BFAR, the Bureau of Fisheries and Aquatic Resources; MCHC, mean corpuscular hemoglobin concentration; MCH, mean corpuscular hemoglobin; MCV, mean corpuscular volume; RBC, red blood cell; WBC, white blood cell.

\section{Introduction}

Fish production plays a significant part in ensuring food security for the Philippines. Tilapia (Oreochromis niloticus) farming has become a source of income among farmers in Central Luzon, the Philippines from the time that the aquaculture industry was established in the region (BFAR 2000). The Bureau of Fisheries and Aquatic Resources (BFAR) is a legitimate government agency that spearheads tilapia aquaculture. The agency allows full utilization of freshwater as a culture system for fish, provides standard regulation for feeding of stocks, and application of pesticides, rodenticides and fertilizers where the impacts of the intensive aquaculture operation on groundwater and aquatic organisms are unknown.

Changes caused by urbanization and industrialization over the years have inevitably contributed to the input of metals in terrestrial and aquatic environments. Heavy metals are of special concern due to their diverse effects, degrees of harmfulness and toxicity to many aquatic animals (Svobodova et al. 1994).

Heavy metal accumulation has been reported in a wide range of ecological systems, such as air, land and water. The increasing levels of heavy metals in ponds presently pose danger to every Filipino who consumes tilapia as an important provider of dietary proteins. Aquatic ecosystems are threatened by the accumulation of heavy metals such as cadmium $(\mathrm{Ca})$, lead $(\mathrm{Pb})$, arsenic (As), mercury ( $\mathrm{Hg})$ and copper $(\mathrm{Cu})$ in tissues of aquatic organisms (Livingstone 2001). Heavy metals undergo bio-accumulation in food chains (Nebel, Wright 1993; Shakoori, Hardy 2006). Heavy metals have different physical properties and physiological effects, and toxic effects on living tissues can occur even at relatively low concentrations, mking them dangerous environmental pollutants (Ferner 2001; Duruibe et al. 2007; Neto et al. 2011). 
In ecological systems, living animals act as reservoirs of toxic metals leading to bio-accumulation. The systemic effect of toxic metals in tilapia needs to be evaluated, especially since transfer of toxic substances from food resources to humans can occur. As tilapia can serve as a reservoir of toxic metals, considering that tilapia aquaculture is important in generating income in the countryside, management and monitoring of potentially harmful metals and chemicals in aquaculture, as well as the health status of fish,are required. In this study we analysed water and tilapia meat for heavy metals in samples obtained from a commercial and a noncommercial fish farm. The grow-out pond of the BFAR was chosen to represent a reputable commercial fish farm based on the intensiveness of its aquaculture operation while a non-intensive backyard fish farm was chosen as a non-commercial counterpart. Information derived from this field investigation served as a reference in defining effective programmes that reduce impending heavy metal accumlation in tilapia freshwater farms.

\section{Materials and methods}

\section{Collection of pond water samples and tilapia meat}

Pond water was sampled at three sites in the commercial (middle part, right and left side of the $10000 \mathrm{~m}^{2}$ BFAR grow-out pond) and the non-commercial (center, right and left side of the $300 \mathrm{~m}^{2}$ private backyard pond) tilapia freshwater ponds. The protocol of the BFAR on collection of pond water samples was adapted. Briefly, three clean plastic bottles, each with $1 \mathrm{~L}$ capacity, were submerged 90 $\mathrm{cm}$ below the surface of the pond for water to collect until the container was full. Collection of water samples was made three times at biweekly intervals.

Samples were obtained from the same ponds but other sites were utilized in succeeding sampling periods (middle, top side and bottom side; and middle, right upper corner and left lower corner). Samples were pooled per collection time and mixed thoroughly before setting aside a $100-\mathrm{mL}$ volume as a representative sample for the analysis of heavy metals.

A total of 150 tilapia individuals (25 individuals per farm per collection time) with average length $15 \mathrm{~cm}$ and average weight of 100 to $200 \mathrm{~g}$ were collected by means of net traps from commercial and non-commercial ponds three times at biweekly intervals. Fish collected for analysis were obtained within the vicinity of the sampling sites for pond water.

The collected fish samples were temporarily placed in an ice box until removal of scales and internal organs and cleaning with distilled water. Fish meat samples taken from each pond during a collection time were pooled, cut finely, mixed thoroughly before taking a $50 \mathrm{~g}$ representative sample, placed in properly labeled plastic bags and stored frozen at $-20{ }^{\circ} \mathrm{C}$ for at least $24 \mathrm{~h}$ before analysis for heavy metals.
Blood collection and evaluation of hematologic parameters Blood samples were collected by cardiac puncture from each fish $(200 \mu \mathrm{L}$ per fish) using a 1-mL tuberculin syringe and a 25-gauge hypodermic needle. Blood samples of tilapia from each farm were pooled in an EDTA-coated vacutainer each sampling time. A volume of $5 \mathrm{~mL}$ was obtained for blood analysis. Total red blood cell (RBC) and total white blood cell (WBC) counts of tilapia were determined in a Neubauer hemocytometer (Germany) after dilution of blood samples with Gower's solution and Turk's solution, respectively. Hematocrit and hemoglobin concentrations were determined using a blood analyzer (Mythic 18R, USA). Values for other RBC indices such as mean corpuscular volume (MCV), mean corpuscular hemoglobin $(\mathrm{MCH})$ and mean corpuscular hemoglobin concentration (MCHC) were computed from standard formulas. Five replicates of blood smears were made from each pooled sample and WBC counts were made after staining the blood smears with Diff-Quik.

\section{Determination of $\mathrm{Cd}, \mathrm{Cu}, \mathrm{Pb}$ and $\mathrm{As}$}

$\mathrm{Cd}, \mathrm{Cu}, \mathrm{Pb}$ and $\mathrm{As}$ in pond water and tilapia meat samples from commercial and non-commercial ponds were evaluated using the methods of Crompton (2002) by flame atomic absorption spectrometry. Briefly, $100 \mathrm{~mL}$ water samples and $50 \mathrm{~g}$ fish meat taken as representative samples from the two ponds were placed separately to dry in crucible dishes in an oven. The samples were placed in a furnace and heated from 100 until $450{ }^{\circ} \mathrm{C}$. The samples were allowed to cool at room temperature for $8 \mathrm{~h}$ before pre-ashing in an infrared radiation lamp. Pre-ashing was done by continuously heating the samples in a furnace at $200^{\circ} \mathrm{C}$, then to $250{ }^{\circ} \mathrm{C}$, and then $450^{\circ} \mathrm{C}$. The samples were again allowed to cool for $8 \mathrm{~h}$ as before, moistened with distilled water and allowed to evaporate in a hot plate. The ash samples were heated in a furnace at 200 to $450{ }^{\circ} \mathrm{C}$ for 1 to $2 \mathrm{~h}$ until samples turned white or gray ash. Five $\mathrm{mL} 6$ $\mathrm{M} \mathrm{HCl}$ was added to the samples, allowed to evaporate in a hot plate before dissolving the residues separately in 10 to $30 \mathrm{~mL} 0.1 \mathrm{M}$ HNO. The samples were allowed to stand for 1 to $2 \mathrm{~h}$ before determination of the $\mathrm{Cd}, \mathrm{Cu}, \mathrm{Pb}$ and $\mathrm{As}$ concnetrations. Levels of $\mathrm{Cd}, \mathrm{Cu}, \mathrm{Pb}$ and $\mathrm{As}$ were derived from linear plots of absorbance values of each sample.

\section{Determination of $\mathrm{Hg}$}

The method of Cherian and Gupta (1990) was used for determination of $\mathrm{Hg}$ by manual cold-vapor atomic absorption spectrometry. One hundred $\mathrm{mL}$ of each pond water sample and $50 \mathrm{~g}$ tilapia meat taken as representative samples from the two ponds were placed separately in digestion flasks before adding 20 boiling stones. Cold distilled water $(5 \mathrm{~mL})$ was added to the samples in flasks during digestion. Sufficient heat was applied for $6 \mathrm{~min}$ to cause a low initial boil in each sample with a strong boil for $10 \mathrm{~min}$ to finish the digestion of each sample. The samples 
Table 1. Heavy metal profiles of pond water. Values represent the levels of heavy metals detected from pond water of the two freshwater tilapia farms. a,b, significant differences of the levels of heavy metals between the two farms $(P<0.05)$

$\begin{array}{lccc}\text { Heavy metal } & \begin{array}{c}\text { Commercial fishpond } \\ \left(\mu \mathrm{g} \mathrm{L}^{-1}\right)\end{array} & \begin{array}{c}\text { Non-commercial fishpond } \\ \left(\mu \mathrm{g} \mathrm{L}^{-1}\right)\end{array} & \begin{array}{c}\left.\text { Permissible limit }(\mu \mathrm{g} \mathrm{L})^{-1}\right) \\ (\mathrm{DENR} 1990)\end{array} \\ \mathrm{Pb} & <14 & <14 & 50 \\ \mathrm{Hg} & 3.60 \mathrm{a} & 4.98 \mathrm{a} & 2 \\ \mathrm{As} & <42 & <42 & 50 \\ \mathrm{Cd} & <1.5 & <1.5 & 10 \\ \mathrm{Cu} & 218.50 \mathrm{a} & 84.67 \mathrm{~b} & 50\end{array}$

were removed from heat before adding two drops of $30 \%$ $\mathrm{H}_{2} \mathrm{O}_{2}$ and washing with $15 \mathrm{~mL}$ distilled water. The digested materials were transferred separately in $100-\mathrm{mL}$ volumetric flasks before evaluating the amount of $\mathrm{Hg}$ in water and fish meat from the commercial and non-commercial farms. Concentration of $\mathrm{Hg}$ was estimated from linear plots of the absorbance values for standard reagent.

\section{Statistical analysis}

Mean $( \pm S D)$ values of metal concentrations in pond water and tilapia meat samples from commercial and noncommercial ponds were determined for three biweekly collections. The mean values $( \pm \mathrm{SD})$ for total $\mathrm{RBC}$ and $\mathrm{WBC}$, hematocrit, $\mathrm{MCV}, \mathrm{MCH}$ and $\mathrm{MCHC}$ per collection period were determined for three biweekly collections. The data were analyzed statistically using the Students' T-test where $P$-values lower than 0.01 and 0.05 were considered significant.

\section{Results}

\section{Heavy metals in pond water}

Accumulation of heavy metals $(\mathrm{Pb}, \mathrm{Hg}, \mathrm{As}, \mathrm{Ca}$ and $\mathrm{Cu})$ in samples from commercial and non-commercial tilapia freshwater ponds are presented in Table 1. Significantly higher $\mathrm{Cu}$ concentration occurred in commercial pond water $(P<0.05)$ compared to that of the non-commercial pond. Both farms contained $\mathrm{Cu}$ levels that were exceedingly higher than the permissible limits of $50 \mu \mathrm{g} \mathrm{L}^{-1}$. Pond water of commercial and non-commercial farms contained similar levels of $\mathrm{Hg}$, which were higher than the permissible limits of $2.0 \mu \mathrm{g} \mathrm{L}^{-1}$. Similar concentrations of $\mathrm{Pb}$, As and $\mathrm{Cd}$ that were lower than allowed levels were noted in the water.

\section{Heavy metals in tilapia meat}

Heavy metal accumulation in tilapia meat from both farms is shown in Table $2 . \mathrm{Pb}$ concentration in tilapia meat from the commercial pond was significantly higher $(P<0.05)$ than in that from the non-commercial ponds. $\mathrm{Pb}$ concentration of fish meat from both farms was higher than the international standard of $300 \mu \mathrm{g} \mathrm{L}^{-1}$. In addition, a significantly higher concentration of $\mathrm{Cu}$ occurred in tilapia meat from the non-commercial farm compared to that from the commercial farm $(P<0.01)$. Similar concentrations of $\mathrm{Hg}$, As and $\mathrm{Cd}$ occurred in tilapia meat from both farms. $\mathrm{Cu}$ and $\mathrm{Hg}$ concentrations in pond water were not significantly correlated with $\mathrm{Cu}$ and $\mathrm{Hg}$ concentrations in tilapia meat.

\section{Total $R B C$ and $R B C$ indices}

Exposure of tilapia to heavy metals may activate physiological responses that can be observed in RBC profiles (Table 3). Tilapia from commercial pond had significantly higher hematocrit $(P<0.01)$ and MCV $(P<$ $0.01)$ compared to tilapia from the non-commercial pond and values were above the normal ranges for hematocrit and MCV. Tilapia from the non-commercial pond had higher MCHC compared to the fish from the commercial pond $(P<0.01)$. Tilapia from both ponds had comparable total RBC (range from 2.06 to $2.07 \times 10^{12}$ cells $\mathrm{mL}^{-1}$ ) and $\mathrm{MCH}$ (range from 39.31 to $40.38 \mathrm{pg}$ ).

\section{Total WBC count and differential counts}

Total WBC and other parameters of tilapia blood in relation to heavy metal concentration from commercial and noncommercial ponds are shown in Table 4. Total WBC and eosinophil counts were similar in fish from both ponds. Tilapia raised in the commercial ponds had significantly

Table 2. Heavy metal profiles of fish meat. Values represent the levels of heavy metals in tilapia meat collected from the two freshwater tilapia ponds. a,b, significant differences of the levels of $\mathrm{Pb}(P<0.05)$ and $\mathrm{Cu}(P<0.01)$ between the two farms

\begin{tabular}{|c|c|c|c|}
\hline Heavy metal & $\begin{array}{l}\text { Commercial fishpond } \\
\qquad\left(\mu \mathrm{g} \mathrm{L}^{-1}\right)\end{array}$ & $\begin{array}{l}\text { Non-commercial fishpond } \\
\qquad\left(\mu \mathrm{g} \mathrm{L}^{-1}\right)\end{array}$ & $\begin{array}{c}\text { Permissible limit }\left(\mu \mathrm{g} \mathrm{L}^{-1}\right) \\
\text { (DENR 1990) }\end{array}$ \\
\hline $\mathrm{Pb}$ & $433.33 a$ & $320.00 \mathrm{~b}$ & 300 \\
\hline $\mathrm{Hg}$ & $<0.10$ & $<0.10$ & 500 \\
\hline As & $<42$ & $<42$ & 2000 \\
\hline $\mathrm{Cd}$ & $<1.5$ & $<1.5$ & No limit \\
\hline $\mathrm{Cu}$ & $0.25 b$ & $131 \mathrm{a}$ & 20000 \\
\hline
\end{tabular}


Table 3. Mean RBC counts and RBC indices of tilapia. Data represent mean $( \pm$ SD) RBC counts and RBC indices (unit of measurement/s) of tilapia from the two freshwater tilapia ponds. ${ }^{*}$, Significant differences at $P<0.01$; and ${ }^{*}$ at $P<0.05$ in the indicated parameters between tilapia from the two farms. Normal values are inside parenthesis below each parameter

\begin{tabular}{lcc} 
Parameters & Commercial pond & Non-commercial pond \\
Total RBC count $\left(\times 10^{12}\right.$ cells $\left.\mathrm{mL}^{-1}\right)(1.91$ to 2.83$)$ & $2.07 \pm 0.06$ & $2.06 \pm 0.07$ \\
\hline Hematocrit $(\%)(27.0$ to 37.0$)$ & $41.02 \pm 1.07^{\star *}$ & $32.49 \pm 1.04$ \\
MCV (fl) $(115.0$ to 183.0$)$ & $199.08 \pm 5.78^{\star *}$ & $153.59 \pm 6.77$ \\
MCH (pg) $(28.3$ to 42.3$)$ & $40.38 \pm 1.43$ & $39.31 \pm 0.92$ \\
MCHC $\left(\mathrm{g} \mathrm{dL}^{-1}\right)(22.0$ to 29.0$)$ & $20.35 \pm 0.66$ & $25.07 \pm 0.99^{* *}$ \\
\hline
\end{tabular}

higher mean neutrophil and monocyte counts compared to those of tilapia from non-commercial ponds $(P<0.01)$. Tilapia from the non-commercial pond had significantly higher mean lymphocyte counts than those of fish from commercial ponds $(P<0.05)$.

\section{Discussion}

Accumulation of heavy metals has become a public concern due to its cumulative effect on the environment. Recent reports describe the contamination of soil (Cherian, Gupta 1990; Nriagu 1995; Aydinalp et al. 2010; Nicholson et al. 2010), water (Cherian, Gupta 1990; Nriagu 1995; Crompton 2002), air (Cherian, Gupta 1990) and plants (Aikpokpodion et al. 2010) with heavy metals. The $\mathrm{Cu}$ and $\mathrm{Hg}$ concentrations of pond water that were higher than permissible or tolerable limits imply heavy metal accumulation in the aquatic environment. Contamination of the aquatic environment can be due to vehicular emissions, farming systems of nearby agricultural lands, which regularly apply fertilizers and pesticides, and air pollutants from industries. High concentrations of $\mathrm{Pb}$ in tilapia meat indicate bio-accumulation. This poses a public health concern, as fish flesh is used chiefly as food Utilization of the liver of European eels in the assessment of heavy metals in polluted estuaries and coastal lagoons has been described (Neto et al. 2011).

Monitoring health status of fish to heavy metal accumulation can assessed by using a full range of physiological indicators, such as hematocrit, $\mathrm{MCV}, \mathrm{MCH}$, $\mathrm{MCHC}$, total RBC, total WBC and differential counts for lymphocytes, neutrophils, monocytes and eosinophils. The response of tilapia to the elevated levels of $\mathrm{Cu}$ and $\mathrm{Hg}$ in commercial and non-commercial ponds pond differed. In the commercial farm these metals caused higher counts of large red blood cells, shown by a high MCV, and a high hematocrit count in tilapia blood, indicating a compensatory mechanism to maximize hemoglobinmediated oxygen carrying capacity of fish RBC. In the noncommercial ponds, high $\mathrm{Cu}$ and $\mathrm{Hg}$ concentrations were associated with a high hemoglobin concentration per RBC, demonstrated by a high MCHC. A high MCHC implies that the oxygen carrying capacity of tilapia RBC, which is mediated largely by hemoglobin, was not compromised. $\mathrm{Cu}$ in high amounts is required for hemoglobin synthesis and stimulates erythrocyte formation (Wells, Weber 1990). A high MCV of Nile tilapia blood (Shakoori, Hardy 2006) and high hematocrit in rainbow trout blood (Vosyliene 1999) have been previously reported, which was a hematologic response triggered by exposure of the fish to $\mathrm{Cu}$. Similar total RBC counts in blood of tilapia from commercial and non-commercial ponds is in agreement with reports on similar RBC counts in blood of several groups of common carp exposed and not exposed to heavy metals (Witeska, Jiezierska 1994).

White blood cell function, indicated by neutrophil and monocyte counts in tilapia from the commercial pond can be explained by mechanisms that attempt to ward off toxic reactions caused by heavy metal accumulation. One significant finding was the predominance of lymphocytes in tilapia from non-commercial pond. The increase in lymphocyte population size indicates cellular responses to the destructive effects of high $\mathrm{Cu}, \mathrm{Hg}$, and $\mathrm{Pb}$ concentrations in the aquatic environment. The prominent neutrophil count noted in the study was in accordance with the findings of Vosyliene (1996) who attributed the same result

Table 4. Mean RBC counts and RBC indices of tilapia. Data represent mean ( \pm SD) RBC counts and RBC indices (unit of measurements) of tilapia from the two freshwater tilapia ponds. ${ }^{*}$, Significant differences at $P<0.01$; and ${ }^{\star}$ at $P<0.05$ in the indicated parameters between tilapia from the two farms. Normal values are inside parenthesis below each parameter

\begin{tabular}{lcc} 
Parameters $\left(\times \mathbf{1 0}^{9}\right.$ cells $\left.\mathbf{L}^{-1}\right)$ & Commercial pond & Non-commercial pond \\
Total WBC count $(21.60$ to 154.70$)$ & $119.71 \pm 1.06$ & $114.31 \pm 2.87$ \\
\hline Lymphocytes $(6.80$ to 136.40$)$ & $95.14 \pm 2.21$ & $104.53 \pm 3.50^{\star}$ \\
Neutrophils $(0.60$ to 9.90$)$ & $14.56 \pm 1.48^{\star *}$ & $7.35 \pm 0.73$ \\
Monocytes $(0.40$ to 4.30$)$ & $8.80 \pm 1.28^{\star *}$ & $3.99 \pm 0.45$ \\
Eosinophils $(0.03$ to 1.60$)$ & $1.60 \pm 0.21$ & $1.25 \pm 0.09$
\end{tabular}


to long-term exposure of rainbow trouts to heavy metals.

In conclusion, the accumulation of heavy metals in the aquatic environment of tilapia presents a risk to the fish population and humans who consume fish as food. Hematological assessment continues to be an effective tool in monitoring health status of fish exposed to various toxic concentrations in the aquatic environment. The data will serve as a reference in carrying out management programmes for pond water, taht are aimed to reduce heavy metal loads.

\section{Acknowledgements}

We thank the staff of the Bureau of Fisheries and Aquatic Resources, Central Luzon State University for their technical assistance.

\section{References}

Aikpokpodion P.E., Lajide L., Aiyesanmi A.F. 2010. Heavy metals contamination in fungicide treated cocoa plantations in Cross River State, Nigeria. Amer. Eurasian J. Agric. Environ. Sci. 8: 268-274.

Aydinalp C., Fuleky G., Tolner L. 2010. The comparison study of some selected heavy metals in the irrigated and non-irrigated agricultural soils. Bulg. J. Agric. Sci. 16: 754-768.

BFAR 2000. Tilapia Hatchery Management. Bureau of Fisheries and Aquatic Resources. NFFTC Aqua-leaflet No. 2000-05.

Cherian L., Gupta V.K. 1990. A simple field test for the detection of mercury in polluted water, air and soil samples. Fresenius J. Anal. Chem. 336: 400-402.

CODEX 1995. General standards for contaminants and toxins in food and feed. Codex Alimentarius, International Food Standard 193-195. WHO/FAO.

Crompton T.R. 2002. Detection of Metals in Natural and Treated Waters. St. Edmundsbury Press. Great Britain.

Duruibe J.O., Ogwuegbu M.O., Egwurugwu J.N. 2007. Heavy metal pollution and human biotoxic effects. Int. J. Phys. Sci. 2: $112-118$.
Ferner D.J. 2001. Toxicity, toxic metals. eMed. J. 2: 1.

Livingstone D.R. 2001. Contaminant-stimulated reactive oxygen species production and oxidative damage to aquatic organisms. Mar. Pollut. Bull. 42: 656-666.

Nebel B.J., Wright R. 1993. Environmental Science: the Way the World Works. $4^{\text {th }}$ Ed. Prentice Hall. New Jersey.

Neto A.F., Passos D., Costa J.L., Costa M.J., Caçador I., Pereira M.E., Duarte A.C., Pacheco M., Domingos I. 2011. Metal concentrations in the liver of the European eel, Anguilla anguilla, in estuaries and coastal lagoons from Portugal. Vie Milieu 61: 167-177.

Nicholson F., Rollett A., Chambers B. 2010. Quantifying heavy metal inputs from organic and inorganic material additions to agricultural soils in England and Wales. 19 ${ }^{\text {th }}$ World Congress of Soil Science, Soil Solutions for a Changing World. August 1-6, Brisbane, Australia.

Nriagu J.O. 1995. Quantitative assessment of worldwide contamination of air, water and soil by trace metals. Nature 6169: 134-139.

Shakooni A.R., Hardy R.D. 2006. Dietary copper exposure and recovery in Nile tilapia Oreochromis niloticus. Aqua Toxicol. 76: 111-121.

Svobodova Z., Vykosova B., Machova J. 1994. Effects of pollutants on selected hematological and biochemical parameters of fish. In: Mueller R., Lloyd R. (eds) Sublethal Chronic Effects of Pollutants on Freshwater Fish, Fishing News Books, UN, pp. 39-52.

Vosyliene M.Z. 1996. Effect of long-term exposure to copper on physiological parameters of rainbow trout. Ekologija 1:3-6.

Vosyliene M.Z. 1999. The effect of heavy metals on hematological indices. Survey of rainbow trout. Acta Zool. Lituanica 9: 13921397.

Wells R.M.G., Weber R.E. 1990. Is there an optimal hematocrit for rainbow trout Onchoryncus mykiss (Walbaum)? An interpretation of recent data based on blood viscosity measurement. J. Exp. Biol. 154: 185-192.

Witeska M., Jiezerska B. 1994. The effect of cadmium and lead on selected blood parameters of common carp. Arch. Pol. Fish 2: 123-132. 